\title{
PENGARUH PELATIHAN DZIKIR TERHADAP PENINGKATAN KEBERMAKNAAN HIDUP PADA MAHASISWA
}

\section{THE EFFECT OF DZIKIR TRAINING TO INCREASING THE MEANINGFULNESS OF LIFE ON STUDENTS}

\author{
Wahyu Kurniawan \\ Rahma Widyana \\ Fakultas Psikologi Universitas Mercu Buana Yogyakarta \\ E-mail: umifaqih4@yahoo.com
}

\begin{abstract}
This study was aimed to examine the effect of dzikir training in increase the meaningfulness of life of students. The hypothesis proposed in this study was there is no difference in meaningfulness of life between subjects who participated in dzikir training (Experimental Group) and subjects who did not participate in dzikir training (Control Group). The increase of meaningfulness of life on subjects in experimental group will be higher than those in control group. This study subjected 12 students from late adolescence that was randomly assigned into 2 groups. 6 subjects are in experimental group, and 6 subjects are in control group. The design of this study is a randomized pretest-posttest control group design. Pretest and posttest was measured with a Life Meaningfulness Scale. The result of a non-parametric analysis (Mann-Whitney Test) showed that the meaningfulness of life of the experimental group significantly higher than those of control group ( $t=0.046 ; p<0.05)$, thus the hypothesis is accepted.
\end{abstract}

Keywords: Dzikir Training, Meaningfulness of Life

\begin{abstract}
ABSTRAK
Penelitian ini bertujuan untuk mengetahui pengaruh pelatihan dzikir terhadap peningkatan kebermaknaan hidup pada mahasiswa. Hipotesis yang diajukan pada penelitian ini adalah ada perbedaan kebermaknaan hidup antara subjek yang mendapatkan pelatihan dzikir dan subjek yang tidak mendapatkan pelatihan dzikir. Subjek yang mendapatkan pelatihan dzikir akan mengalami peningkatan kebermaknaan hidup lebih tinggi daripada subjek yang tidak mendapatkan Pelatihan Dzikir. Subjek dalam penelitian sebanyak 12 orang mahasiswa remaja akhir. Subjek dibagi menjadi 2 kelompok yaitu 6 orang subjek sebagai kelompok eksperimen, dan 6 orang subjek sebagai kelompok kontrol. Penempatan subjek dalam kelompok dilakukan secara random. Desain yang digunakan dalam penelitian ini adalah randomized pretest-posttest control group design. Pengukuran pre test dan post test menggunakan Skala Kebermaknaan Hidup. Metode analisis yang digunakan adalah analisis non parametrik (Mann-Whitney Test). Hasil uji hipotesis pada kelompok eksperimen dengan kelompok kontrol diketahui nilai $t$ sebesar $=0,046(p<0,05)$. Berdasarkan analisis tersebut berarti ada perbedaan peningkatan kebermaknaan hidup antara kelompok eksperimen dan kelompok kontrol sehingga hipotesis diterima.
\end{abstract}

Kata kunci: Pelatihan Dzikir, Kebermaknaan Hidup. 
Perubahan dunia sekitar, baik yang bersifat konstruktif maupun destruktif, menjadi bagian yang tak terpisahkan dalam kehidupan manusia. Setiap terjadi perubahan lingkungan, manusia harus mengambil keputusan instrinsik pribadi sebagai konsekuensi interaksi manusia dengan dunia sekitarnya (Sumanto, 2006).

Globalisasi dan moderenisasi ternyata tidak hanya membawa dampak positif, tetapi juga berdampak negatif yang dirasakan dalam kehidupan masyarakat Indonesia. Globasisasi telah menyebabkan banyak perubahan di dalam kehidupan manusia, misalnya perubahan dalam kehidupan sosial masyarakat, antara lain menyangkut perubahan nilai, moral, dan etika kehidupan (Hawari, 1988). Tidak semua orang mampu menyesuaikan diri terhadap perubahan lingkungannya, termasuk remaja (Supriadi, 2006).

Remaja merupakan individu yang mudah berubah akibat adanya modernisasi. Hal ini dikarenakan remaja berada pada masa transisi dari kehidupan anakanak ke masa dewasa yang ditandai dengan perubahan dan perkembangan yang pesat baik dari segi fisik maupun psikis (Monks, Knoers, \& Haditono, 2009). Dapat dikatakan bahwa perjalanan masa kanak-kanaknya telah mengantar ke sebuah pintu usia remaja menjadi sosok individu yang berbeda berdasarkan perasaan dan cara pandang baru terhadap lingkungannya (Fillah, dalam Haryanto, 2003). Lebih lanjut Harre dan Lamb (1996) mengemukakan bahwa masa remaja merupakan masa idealisme. Pada masa ini standar-standar dan moral masyarakat diteliti, ditantang, dan bahkan ditolak. Masa transisi dan idealisme inilah yang membawa remaja pada pencarian jati diri, siapakah dirinya yang sebenarnya, hingga pada suatu pertanyaan apakah remaja mampu memberi makna dalam kehidupannya.

Kebermaknaan hidup adalah sesuatu yang dipandang penting, benar dan didambakan, memberikan nilai khusus serta dapat dijadikan tujuan hidup seseorang. Apabila berhasil ditemukan dan dipenuhi, maka kehidupan akan menjadi berarti dan menimbulkan perasan bahagia. Makna hidup tidak dapat dipisahkan dengan tujuan hidup, yakni hal-hal yang perlu dicapai dan dipenuhi (Yallom, dalam Sumanto, 2006). Crumbaugh dan Maholick (Koeswara, 1992) mengemukakan bahwa kebermaknaan hidup adalah seberapa tinggi individu mengalami hidupnya bermakna.

Senada dengan pandangan di atas, Frankl (2004) mengatakan bahwa makna hidup adalah sesuatu yang objektif, menuntut, mutlak, dan terpisah dari kerja individu kecuali kerja yang merupakan suatu usaha untuk memberikan sesuatu kepada hidupnya dan sesama. Remaja yang memiliki makna dalam hidupnya akan menjalani kehidupan sehari-hari dengan semangat dan gairah hidup serta jauh dari perasaan hampa. Remaja menyadari bahwa makna hidup dapat ditemui dalam hidup itu sendiri. Kalaupun pada suatu saat mereka dalam situasi yang tidak menyenangkan, maka remaja 
akan menghadapi dengan tabah. Individu sadar bahwa ketika Allah menurunkan cobaan pada hambanya pasti ada makna dan hikmah di balik cobaan itu (Bastaman, 1996).

Begitu juga sebaliknya, remaja yang tidak berhasil dalam menemukan makna hidupnya akan mengalami kekecewaan dan kehampaan hidup yang pada akhirnya menimbulkan gangguan perasaan yang cukup menghambat prestasi dan penyesuaian diri. Gangguan ini terwujud dalam keluhan-keluhan serba bosan, hampa dan penuh keputusasaan, kehilangan minat dan inisiatif, serta merasa bahwa hidup ini tidak ada artinya sama sekali (noogenic neurosis); mengembangkan karakter-karakter kepribadian totaliter yang merupakan gambaran pribadi dengan kecenderungan untuk memaksakan tujuan, kepentingan, dan kehendaknya sendiri dan tidak bersedia menerima masukan dari orang lain lebihlebih apabila masukan tersebut berbeda dengan pandangannya (totalitarianism); dan mengembangkan pribadi dengan kecenderungan kuat untuk selalu mengikuti dan menyesuaikan diri kepada tuntutan lingkungan sekitarnya serta bersedia pula untuk mengabaikan keinginan dan kepentingan dirinya sendiri (conformism) (Bastaman, 2005).

Remaja merupakan aset terbesar dalam pembangunan. Hal ini berarti kelompok remaja harus dipersiapkan sedemikian rupa agar remaja tersebut tumbuh dan berkembang menjadi generasi muda yang tangguh. Ketang-

guhan dalam hal ini terutama dilihat dari segi mental, berjiwa ksatria, kreatif, inovatif dan produktif (Purwanti, 2001).

Dalam perkembangannya, remaja dibagi menjadi tiga tahapan, yaitu remaja awal 12-15 tahun, remaja madya 15-18 tahun, dan remaja akhir 18-21 tahun (Monks dkk, 2009). Pada masa remaja awal, remaja tersebut belum mampu menginternalisasikan nilai-nilai yang ada dalam dirinya dan masyarakat, karena remaja disibukkan dengan body image (citra diri) dan memiliki emosi yang labil, sehingga upaya pencarian dorongan untuk hidup dan sesuatu yang dipandang bernilai baru dimulai pada masa remaja madya. Pencarian ini merupakan salah satu proses untuk menemukan standar nilai yang ada. Masa remaja madya menghantarkan seseorang pada masa remaja akhir, sehingga pada masa remaja akhir individu telah menemukan standar nilai dan pendirian hidup (Yusuf, 2004).

Remaja akhir telah mampu menginternalisasikan penilaian moral dan menjadikan nilai pribadi sendiri (Furter, dalam Monks dkk, 2009). Moral yang terbentuk menjadikan remaja mampu membedakan baik dan buruknya suatu hal. Seorang remaja bermoral akan memiliki pandangan religius atau berketuhanan, yang berarti menyandarkan segala urusan pada Tuhan yang maha kuasa. Penyerahan diri kepada Tuhan akan membuat kehidupan remaja penuh bermakna. Hal ini berarti seorang remaja akhir yang memiliki tingkat religisitas 
yang baik dan bermoral (Rumke, dalam Monks dkk, 2009),

Adapun ciri-ciri seorang individu yang memiliki kebermaknaan hidup ditandai dengan: kebebasan berkehendak, kepuasan hidup, makna hidup, sikap terhadap kematian, pikiran tentang bunuh diri, dan kepantasan hidup (Crumbaugh \& Maholick, dalam Koeswara, 1992). Adanya masa transisi atau peralihan pada remaja, serta perubahan yang terus menerus baik lingkungan sosial maupun fisik, dapat mengakibatkan remaja sulit untuk menyesuaikan diri sehingga mengalami konflik baik diri sendiri, lingkungan, keluarga, teman maupun lingkungan sosialnya. Selanjutnya akan muncul perasaan bingung, tidak menentu, putus asa, cemas, teralienasi, depresi, kacau, mudah terombang ambing, dan tidak mempunyai pegangan dsalam diri remaja. Akibatnya, remaja tidak tahu pasti masa depannya, mengalami keraguan dan akhirnya frus-trasi dan tidak percaya diri. Hal tersebut termanifestasi dalam bentukbentuk kena-kalan remaja, seperti minumminuman beralkohol, penyalahgunaan narkotika, mencuri, memperkosa bahkan sampai kriminal serius (Rahman, dalam Hartati, 2002).

\section{Berdasarkan data BNN} (www.regional. kompas.com) hingga tahun 2008, jumlah pengguna narkoba di Indonesia mencapai 3,2 juta orang, atau sekitar 1,99 persen dari jumlah penduduk di Indonesia. Sedangkan pada tahun 2009 terjadi 28.382. Jumlah ini meningkat tajam dibanding tahun sebelumnya. Dari kasus penyalahgunaan narkoba itu, sebanyak 9.661 kasus adalah kasus narkotika, 8.698 kasus psikotropika, dan 10.023 kasus zat berbahaya lainnya. Sebagian besar pelaku berusia di atas 30 tahun. Sebanyak 102 tersangka masih berusia di bawah 15 tahun dan 1.596 lainnya remaja berusia 18-22 tahun.

Hasil wawancara yang dilakukan peneliti terhadap 20 mahasiswa yang merupakan remaja akhir (18-21 tahun) menunjukkan bahwa 8 orang di antara mereka mengalami keputusasaan, merasakan hidup tidak perlu dipikirkan dan mengikuti arus, tidak memiliki cita-cita dan tujuan hidup, apatis dan mudah mengeluh. Hasil observasi menunjukkan bahwa 8 orang di antara mereka terjerumus kepada minum-minuman keras, terlibat perkelahian, jarang mengikuti perkuliahan, melakukan petualangan seksual (seks bebas).

Menurut Koeswara (1992), ada beberapa gejala sebagai akibat dari orang yang memiliki ketidakbermaknaan hidup, antara lain terjerumus pada penyalahgunaan narkotika dan obat-obatan terlarang, minum-minuman keras, perjudian, pencurian, pembunuhan, pemerkosaan, melakukan petualangan di bidang seksual (seks bebas), bunuh diri, dan berbagai tindakan kriminal lainnya yang merugikan kepentingan pribadi serta masyarakat. Fenomena penyalahgunaan narkoba, minum-minuman keras, seks bebas yang dilakukan oleh individu merupakan efek dari belum adanya penghayatan atau orientasi positif terhadap nilai-nilai hidup. 
Menurut Crumbaugh dan Maholick (Koeswara, 1992), kekurangan makna hidup mengisyaratkan kegagalan individu dalam menemukan pola tujuan-tujuan dan nilai-nilai yang terintegrasi di dalam hidup, sehingga hal tersebut membuat individu menjadi lemah dan kehilangan semangat untuk berjuang dalam mengatasi hambatan untuk mencapai makna hidup.

Menurut Bastaman (1996), ada beberapa faktor yang memengaruhi tingkat kebermaknaan hidup seseorang yaitu: (1) kualitas Insani, yaitu semua kemampuan, sikap, sifat, dan kondisi yang semata-mata terpatri dan terpadu dalam eksistensi manusia, meliputi inteligensi, kesadaran diri, kreativitas, kebebasan, dan tanggung jawab. Kualitas yang dimiliki insan/ individu ini akan memengaruhi keber-maknaan hidupnya. (2) Encounter, yaitu hubungan mendalam antara seseorang pribadi dan pribadi lain. Hubungan tersebut ditandai dengan penghayatan, keakraban serta sikap dan kesediaan untuk saling menghargai, memahami, dan menerima satu sama lain. (3) Ibadah, yaitu suatu bentuk kepatuhan manusia kepada Tuhannya yang direalisasikan dengan cara menjalankan segala perintah dan menjauhi larangannya, serta berbuat baik kepada sesama ataupun makhluk Tuhan lainnya. (4) Nilai-nilai, yaitu suatu keyakinan yang digunakan sebagai pedoman oleh seseorang dalam melakukan tindakan ataupun dalam menentukan berbagai pilihan dalam hidup.
Salah satu upaya dalam peningkatan kebermaknaan hidup adalah melalui ibadah (Bastaman, 2005). Sejalan dengan ini, Yalom (Sumanto, 2006) berpendapat bahwa salah satu sumber kebermaknaan hidup adalah keyakinan akan keberadaan Tuhan. Pendekatan diri kepada Tuhan adalah mengembalikan manusia kepada naluri dasarnya, yaitu insting keberagamaan. Naluri ini mendorong manusia untuk mengadakan kegiatan keberagamaan, karena manusia beragama pada dasarnya adalah manusia yang sturuktur mental keseluruhan dan kehidupannya diarahkan kepada Tuhan.

Zikir dalam ajaran Islam adalah salah satu cara untuk mendekatkan diri kepada Allah (Subandi, 2009). Sebagaimana Firman Allah dalam Surat AL-Insan ayat 25-26 :

"Dan sebutlah nama Tuhanmu (Dzikir) diwaktu pagi dan petang, dan di sebagian malam dan bersujudlah kepadanya seraya bertasbih pada malam yang panjang"

Dan Firman Allah dalam surat AIMukminun ayat 115 :

"Maka apakah kamu mengira, bahwa sesungguhnya kami menciptakan kamu secara mainmain, dan bahwa kamu tidak dikembalikan kepada kami?"

Dzikir ialah sebuah bentuk ketaatan yang diniatkan karena Allah dengan membaca asma Allah. Sebagaimana yang dikemukakan oleh Hawwa (Eniatun, 2004), zikir ialah doa amaliah (praktis) 
dan setiap doa adalah dzikir kepada Allah, karena di dalamnya terdapat penggunaan, pengenalan, dan pengaduan serta permohonan kepada Allah.

Senada dengan pendapat di atas, Ilham (2005) menambahkan dzikir artinya mengingat. Dengan demikian dzikkrullah berarti mengingat dan menyebut asma Allah. Ingat ialah gerakan hati, sedangkan sebutan ialah gerak lisan. Jadi dzikir yang terbaik ialah perpaduan antara dzikir hati dan lisan menyebutnya dengan kalimat tauhit, tahmid, taqlis, takbir, tasmiyah, qiro'atul quraan dan doa matsyur dari Rasulullah. Dzikir yang dilakukan dengan khusuk akan diberikan sifat Al-Furqon yang artinya dapat membedakan perbuatan yang baik dan yang buruk.

Berdasarkan pengertian di atas dapat diambil sebuah pengertian bahwa dzikir ialah suatu usaha yang terencana secara sistematis dan terencana baik pengetahuan, sikap, dan perilaku dengan tujuan agar individu mampu menjadikan setiap aktivitas pikir, rasa dan perbuatan dalam kerangka berdzikir (mengingat dengan sadar) kepada Allah. Dikatakan oleh Haryanto (1996), terapi dzikir memiliki keterkaitan dengan penyalahgunaan narkotika. Ternyata pengalaman melalui terapi dzikir, dzikir memegang peranan penting dalam usaha penyembuhan ketergantungan obat terlarang.

Alasan digunakannya pelatihan sebagai metode pelaksanaan dzikir adalah karena di dalam pelatihan ada unsur belajar pengalaman. Belajar dari pengalaman adalah suatu proses yang dalam kehidupan sehari-hari juga terjadi secara terus menerus, namun proses itu memakan waktu yang sangat lama, dan sering kali pengalaman tersebut dianggap tidak pernah ada. sehingga pengalaman itu menjadi bermanfaat bagi kehidupan selanjutnya. Hal inilah yang terjadi dalam sebuah pelatihan (Creamer \& Siregar, dalam Hartati, 2002).

Pelatihan Dzikir dirancang mengacu pada prinsip experiential learning yang dikemukakan oleh Dewey (Budiarto, 1982). Dewey mengatakan pemikiran harus berpijak pada pengalaman (experience), dan bergerak kembali menuju ke pengalaman - pengalaman berikutnya, Dewey berpendapat bahwa titik tuju dan titik tolak dari pemikiran adalah pengalaman. Pada mulanya pemikiran bangkit karena adanya pengalaman yang menyulitkan dan pada akhirnya pemikiran membuat pemecahan yang akan mempunyai akibat merubah situasi (Budiarto, 1982).

Pelatihan Dzikir yang diharapkan akan dapat meningkatkan kebermaknaan hidup yang dituang ke dalam modul yang tersusun berdasarkan teori yang dibuat oleh Hartati (2002). Proses Pelatihan Dzikir ini meliputi sepuluh sesi, sebagaimana modul yang pernah dibuat oleh Hartati (Purba, 2005), yaitu (1) Bina suasana, (2) Sesi Ma'rifatullah, (3) Sesi ma'rifatul Insan, (4) mendengar dan mentadaburi Al-Qur'an (5) tadzkiyatun nafs (pembersihan jiwa), (6) Sholat, (7) dzikir dan wirid, (8) problematika hidup, 
(9) sholat malam, dan (10) Muhasabah (perenungan).

Dzikir dapat berfungsi sebagai pengendalian diri, pengendalian hawa nafsu, mencegah kemungkaran, menjadi lebih sabar, lapang dada, dan meningkatkan kebermaknaan hidup (Ilham, 2005). Oleh sebab itu pelatihan Dzikir dapat digunakan sebagai sarana untuk meningkatkan kebermaknaan hidup.

Berdasarkan permasalahan di atas dapat diketahui bahwa remaja pada masa transisi remaja tersebut mengalami ambivalensi terhadap perubahan, remaja menginginkan dan menuntut kebebasan sedangkan remaja sering takut bertanggung jawab akan akibat, sehingga mengalami kegoncangan batin. Di sisi lain remaja belum bisa melaksanakan fungsi dan tanggung jawab sebagai orang dewasa. Padahal salah satu tugas perkembangan penting yang harus dikuasai oleh remaja adalah mengganti konsep moral yang berlaku dimasa kanak-kanak dengan prinsip moral yang berlaku umum pada remaja yang dijadikan pedoman dalam bertingkah laku.

Remaja harus dapat menemukan kebermaknaan hidupnya. Untuk menemukan serta meningkatkan makna hidup dapat dilatih salah satunya melalui dzikir. Pelatihan Dzikir adalah salah satu usaha sistematis untuk mengingat Allah dalam segala aktivitas ibadah melalui membaca tasbih, tahmid, takbir membaca Al-Quran, sholat. dalam penelitian ini yang ingin peneliti ajukan adalah apakah ada pengaruh positif Pelatihan Dzikir terha- dap peningkatan kebemaknaan hidup pada mahasiswa. Hipotesis yang diajukan dalam penelitian ini adalah ada perbedaan kebermaknaan hidup antara subjek yang mendapatkan Pelatihan Dzikir dengan subjek yang tidak mendapatkan Pelatihan Dzikir. Subjek yang mendapat pelatihan Dzikir akan mengalami peningkatan kebermaknaan hidup lebih tinggi daripada subjek yang tidak mendapat Pelatihan Dzikir.

\section{METODE PENELITIAN}

\section{Subjek Penelitian}

Subjek penelitian adalah Mahasiswa di Asrama B Yogyakarta yang memiliki skor kebermaknaan hidup rendah dan sedang. Seleksi subjek dilakukan dengan memberikan Skala Kebermaknaan Hidup yang telah diuji validitas dan reabilitasnya kepada 50 subjek. Selanjutnya data yang diperoleh akan dikategorisasikan ke dalam 3 kelompok, yaitu tinggi, sedang, rendah. Kategori ini bertujuan untuk memilih subjek yang dijadikan sebagai subjek penelitian berdasarkan kriteria yang telah ditentukan.

\section{Desain Penelitian}

Penelitian ini menggunakan desain eksperimen randomized pretest-posttest control group design yang terdiri atas dua kelompok, yaitu kelompok eksperimen dan kelompok kontrol sebagai pembanding. Kelompok eksperimen akan mendapatkan pelatihan dzikir. Dengan 
berbagai perlakuan yang terdiri dalam 10 materi dan sesi. Kelompok kontrol tidak diberikan perlakuan apapun dengan tujuan untuk mengetahui perbedaan kebermaknaan hidup diantara subjek yang diberikan Pelatihan Dzikir dengan yang tidak diberikan Pelatihan Dzikir. Berdasarkan metode data sebelumnya, penelitian ini dianalisis menggunakan teknik Independent sampel $\mathrm{t}$-Test dan paired sampel t-Test. Berhubung jumlah subjek masing-masing kelompok kecil (hanya 12 orang) maka selisih postest dan prates dianalisis menggunakan statistik non parametrik (Mann-Whitney Test) untuk mengetahui perbedaan peningkatan kebermaknaan hidup antara KE dan KK.

Rancangan eksperimen tersebut sebagai berikut :

$\begin{array}{cccc}\text { KE } & \text { TI } & X & \text { T2 } \\ \text { KK } & \text { TI } & -X & \text { T2 }\end{array}$

Keterangan :

$\mathrm{R}=$ Random Assignment

$\mathrm{KE}=$ Kelompok Eksperimen

$\mathrm{KK}=$ Kelompok Kontrol

$\mathrm{T} 1=$ Pretest kebermaknan Hidup

$\mathrm{T} 2=$ Pascates

$\mathrm{X}=$ Perlakuan berupa pelatihan Dzikir

$-X=$ Tanpa perlakuan Pelatihan Dzikir

\section{Metode Pengumpulan Data}

Metode pengumpulan data yang digunakan untuk mengukur variabel kebermaknaan hidup dengan menggunakan skala kebermaknaan hidup berpedo- man pada PIL (Purpose In Life) yang dikemukakan oleh Crumbaugh dan Maholick berdasarkan aspek-aspek kebermaknaan hidup (Bastaman, 1996).

Subjek diminta untuk menjawab pertanyaan dengan cara memilih salah satu dari alternatif jawaban yang tersedia antara lain ialah sangat sesuai, sesuai, tidak sesuai, dan sangat tidak sesuai. Skor pada pertanyaan favorable bergerak dari 4 sampai 1 , nilai 4 tertinggi diberikan pada jawaban sangat sesuai, 3 untuk jawaban sesuai, 2 untuk jawaban tidak sesuai, 1 untuk jawaban sangat tidak sesuai. Sebaliknya skor untuk pertanyaan unfavorable bergerak dari 1 sampai 4 . Nilai 4 untuk sangat tidak sesuai, 3 untuk tidak sesuai, 2 untuk jawaban sesuai, 1 untuk jawaban sangat sesuai. Semakin tinggi skor berarti subjek memilki tingkat kebermaknaan hidup yang tinggi. Skala kebermaknaan hidup berjumlah 48 aitem. Sebelum digunakan, aitem skala diuji validitas terlebih dahulu dengan tujuan untuk mengetahui sejauhmana kecermatan dan ketepatan dapat diberikan pada hasil penelitian. Alat ukur dinyatakan valid apabila memperoleh koefsien validitas minimal 0,25. Berdasarkan ketentuan tersebut, aitem yang memilki koefisien korelasi di bawah 0,25 dinyatakan gugur atau tidak digunakan dalam penelitian (Azwar, 2003). Berdasarkan hasil tersebut, aitem yang memiliki koefisien validitas kurang dari 0,25 dianggap gugur atau tidak valid untuk dipakai sebagai alat ukur. Item yang semula berjumlah 48 item berkurang 
menjadi 30 aitem setelah uji coba. adapun koefesien validitas bergerak dari 0,26 hingga 0,589 . Koefisien reliabilitas berkisar antara 0,00 sampai 1,00 nilai reliabilitas jika mendekati 1,00 berarti semakin tinggi reliabilitas, sebaliknya jika koefisien reliabilitas semakin rendah apabila mendekati angka 0,00. Berdasarkan hasil uji reliabilitas koefisien diperoleh 0,782 .

\section{Intervensi Penelitian}

Subjek dalam kelompok eksperimen diberi perlakuan, yaitu Pelatihan Dzikir yang terdiri atas 10 materi dan sesi, pelatihan tersebut menggunakan metode (experience learning), diskusi, dan ceramah. Adapun materi dan sesi Pelatihan Dzikir antara lain bina suasana, Ma'rifatullah, Ma'rifatul insan, mendengarkan dan mentadaburi Al-Qur'an, tazkiyatun Nafs, Dzikir dan Wirid, sholat, problematika hidup, qiyamullail dan muhasabah. Pelatihan dilaksanakan selama 2 hari. Hari pertama dilaksanakan sesi Bina Suasana (60 menit), Ma'rifatullah (110 menit), Ma'rifatul Insan (160 menit), mendengarkan dan mentadaburi Al Qur'an (90 menit) dan tazkiyatunnufs (120 menit), Total waktu pelatihan di hari pertama adalah 540 menit atau 9 jam. Hari kedua dilaksanakan sesi Dzikir dan Wirid (140 menit), sesi sholat (160 menit), problematika hidup (120 menit), qiyamullail (60 menit) dan muhasabah (60 menit). Total waktu pelatihan di hari kedua juga 9 jam. Modul Pelatihan Dzikir disusun dalam penelitian ini mengguna- kan modul yang disusun oleh Hartati berdasarkan teori Ilham (2005), Wahid (Mubarok, 1994), Stoltz (Sumanto, 2006), Ancok (2008). Sebelum modul digunakan, terlebih dahulu dilakukan professional judgement dari dua orang pakar pelatihan spiritual terhadap modul dan uji coba modul, untuk mengevaluasi kesesuaian dan ketepatan isi modul.

\section{Metode Analisis Data}

Analisis yang digunakan adalah metode statistik untuk menguji perbedaan kebermaknaan hidup antara kelompok eksperimen yang diberikan perlakuan dengan kelompok kontrol yang diberikan perlakuan dengan teknik analisis (Mann Whitney Test) Data yang akan dianalisis adalah "Gain Score" yaitu selisih nilai skor pratest dan skor pascates. Kemudian dicari rerata sehingga diketahui kelompok mana yang memiliki kebermaknaan hidup lebih tinggi setelah adanya perlakuan berupa Pelatihan Dzikir.

\section{HASIL PENELITIAN}

Data yang diperoleh dari prates dan pascates Skala Kebermaknaan Hidup digunakan sebagai dasar pengujian hipotesis. Data penelitian yang diperoleh dianalisis dengan menggunakan tiga cara, yaitu analisis deskriptif untuk menggambarkan dinamika perubahan psikologis yang dialami oleh masing-masing subjek pada kelompok eksperimen, analisis statistika non parametrik (Mann-Whitney 
Test) yang digunakan untuk melihat perbedaan kebermaknaan hidup antara kelompok eksperimen dan kelompok kontrol berdasarkan perbedaan selisih antara pascates dan prates (gained score) sesudah Perlakuan Dzikir, dan analisis kualitatif (untuk melihat perubahan dan perkembangan setiap subjek dari awal sampai akhir proses penelitian).

\section{Analisis deskriptif}

Skala Kebermaknaan Hidup (I-II) memiliki skor minimal hipotetik sebesar $1 \times 30=30$, skor hipotetik $4 \times 30=120$, standar deviasi sebesar 120-30:6= 15 dan rerata hipotetiknya adalah $120+30: 2=$ 75. Deskripsi data hipotetik penelitian menunjukkan bahwa nilai minimal subjek 30 , nilai maksimal 120 , rata-rata 75 , dan standar devisi 15.

Hasil pengumpulan skor prates menunjukkan skor kebermaknaan hidup pada kelompok eksperimen terendah 56 dan tertinggi 88 dengan rerata 72,67 . Sedangkan pada kelompok kontrol skor terendah 58 dan tertinggi 89 dengan ratarata 75,33 . Deskripsi data empirik prates dan pascates penelitian dapat dilihat pada tabel 8 berikut ini:

Tabel 1. Data empirik prates dan pascates

\begin{tabular}{lrrllll}
\hline & \multicolumn{3}{c}{ Prates } & \multicolumn{4}{c}{ Pascates } \\
\cline { 2 - 7 } Kelp & Min & Maks & mean & Min & Maks & Mean \\
\hline KE & 56 & 88 & 72,67 & 93 & 114 & 99,33 \\
\hline KK & 58 & 89 & 75,33 & 75 & 95 & 82,33 \\
\hline
\end{tabular}

Berdasarkan data hipotetik, kategorisasi Prates dan Pascates dapat dilakukan kategorisasi. Deskripsi dilihat pada tabel 2 berikut ini:

Tabel 2. Kategorisasi prates dan pascates

\begin{tabular}{ccccrc}
\hline Rumus & Katagori & KE & \multicolumn{3}{c}{ KKI } \\
\cline { 3 - 6 } & & Prates & Pascates & Prates & Pascates \\
\hline$X \geq 90$ & Tinggi & 0 & 6 & 0 & 1 \\
\hline $60 \geq X<$ & Sedang & 4 & 0 & 5 & 5 \\
90 & & & & & \\
\hline$X<60$ & Rendah & 2 & 0 & 1 & 0 \\
\hline
\end{tabular}

Hasil kategorisasi di atas menunjukkan bahwa ada perbedaan antara kelompok eksperimen dan kelompok kontrol. Dalam kelompok eksperimen, subjek yang terdiri atas 4 subjek dalam kategori sedang mengalami peningkatan kategori menjadi tinggi, dan 2 subjek dalam kategori rendah menunjukkan 
adanya peningkatan menjadi kategori tinggi. Sedangkan dalam kelompok kontrol, 5 subjek yang semula pada kategori sedang menunjukkan tidak adanya perubahan karena kelompok kontrol tidak diberikan Pelatihan Dzikir. Sedangkan 1 subjek yang semula pada kategori rendah menjadi tinggi, hal ini dikarenakan waktu pelaksanaan penelitian dilakukan dua minggu mendekati bulan ramadhan sehingga memungkinkan subjek melakukan mendekatkan diri kepada Allah.

\section{Uji Statistika}

Hasil perhitungan menggunakan (Mann-Whitney Test) pada selisih nilai (gain score) pascates dan prates antara kelompok eksperimen (KE) dan Kelompok kontrol (KK) diperoleh koefisien perbedaan sebesar 0,046 ( $p$ >0,05), sehingga dapat disimpulkan bahwa ada perbedaan peningkatan kebermaknan hidup antara kelompok eksperimen dan kelompok kontrol. Dengan hipotesis yang diajukan pada penelitian ini diterima (signifikan). Grafik peningkatan gain score prates dan pascates pada kelompok KE dan KK dapat dilihat pada gambar 1 dan 2.

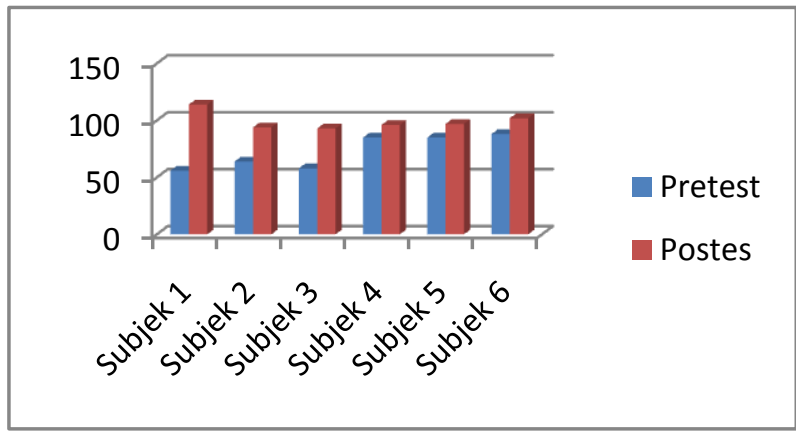

Gambar 1. Grafik Peningkatan Gain score KE

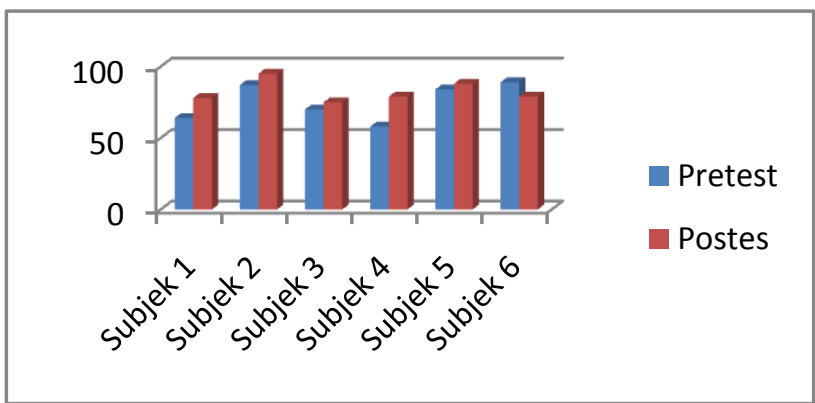

Gambar 2. Grafik Peningkatan Gain score KK 


\section{Analisis kualitatif}

Analisis kualitatif dilakukan untuk melihat perkembangan subjek dari awal perlakuan pelatihan dzikir sampai pengukuran terakhir (postest) dengan menggunakan observasi dan wawancara. Analisis data kualitatif dilakukan pada setiap subjek kelompok eksperimen agar dapat diketahui lebih mendalam perubahan yang dialami melalui sesi-sesi yang disajikan dalam perlakuan dzikir baik harapan dan manfaat yang segera dirasakan setelah mengikuti dzikir, serta perubahan perilaku yang akan diaplikasikan subjek setelah menjalani dzikir.

Berdasarkan hasil observasi dan wawancara terhadap masing-masing subjek diketahui bahwa secara umum subjek penelitian pada awal penelitian mengalami ketidakbermaknaan hidup. Selanjutnya setelah mengikuti dzikir, semua subjek dalam kelompok eksperimen yaitu $100 \%$ (6 orang) melaporkan perkembangan dirinya lebih positif yaitu merasakan ketenangan. Selanjutnya perkembangan kemajuan subjek kelompok eksperimen dari awal sampai akhir penelitian diuraikan di bawah ini.

\section{a. Subjek 1 (nama initial: NT)}

Skor kebermaknaan hidup sebelum mengikuti Pelatihan Dzikir adalah 56 sedangkan skor kebermaknaan hidup setelah dzikir adalah 114, skor kebermaknaan hidup sebelum Pelatihan Dzikir masuk dalam katagori rendah dan setelah terapi subjek mengalami peningkatan kebermak- naan hidup sebesar 58, subjek mengalami peningkatan kebermaknaan hidup paling tinggi dibandingkan subjek lain.

Obeservasi selama pelatihan menunjukkan bahwa subjek adalah peserta yang mengikuti Pelatihan Dzikir dengan antusias. Subjek memiliki interaksi yang baik dengan peserta lain dan mampu mengungkapkan perasaannya saat diforum hingga menangis ketika sharing saat problematika hidup.

Dari hasil wawancara yang dilakukan kepada subjek setelah mengikuti dzikir subjek mengungkapkan bahwa subjek merasa lebih tenang, damai serta merasakan ada perubahan wawasan terlebih tentang keagamaan sehingga semakin merasa dekat dengan Allah SWT, setiap setelah melakukan ibadah sholat maghrib subjek melakukan dzikir. Subjek mengaku sebelum mengikuti Pelatihan Dzikir kondisi subjek diliputi perasaan bimbang, ragu dan kurang memahami keberadaan Allah lebih dekat. Subjek merasa sesi yang sangat berkesan adalah sesi ma'rifatullah. Setelah Pelatihan Dzikir kondisi fisiknya lebih segar dan lebih bersemangat, terutama ketika sholat membuat hati menjadi tenang dan damai.

\section{b. Subjek 2 (nama initial: RR)}

Skor kebermaknaan hidup sebelum mengikuti Pelatihan Dzikir adalah 
64, sedangkan skor keber-maknaan hidup setelah dzikir adalah 94. Skor kebermaknaan hidup sebelum Pelatihan Dzikir masuk dalam katagori sedang dan setelah terapi subjek mengalami peningkatan kebermaknaan hidup sebesar 30 .

Obeservasi selama pelatihan menunjukkan bahwa subjek adalah peserta yang mengikuti Pelatihan Dzikir dengan antusias yang kurang hal ini dikarenakan RR adalah salah satu penghuni tetap di asrama. Subjek sedikit mengalami kesulitan dalam mengkomunikasikan sesuatu. Hal ini dikarenakan kesulitan dalam penggunaan bahasa Indonesia secara baik dan benar. Dari hasil wawancara yang dilakukan kepada subjek setelah mengikuti dzikir subjek mengungkapkan bahwa subjek merasakan ketenangan yang lebih baik dibandingkan dengan sebelum diberi-kan pelatihan, merasa lebih rileks dan menganggap semua masalah yang pernah ada adalah sebagai pembelajaran, terlebih setelah mengikuti materi problematika hidup.

\section{c. Subjek 3 (nama initial: WW)}

Berdasarkan dari skor kebermaknaan hidup sebelum mengikuti terapi dzikir adalah 58, sedangkan skor kebermaknaan hidup setelah dzikir adalah 93. Hal ini menunjukkan bahwa subjek mengalami peningkatan yang semula masuk dalam katagori rendah menjadi katagori tinggi.
Obeservasi selama pelatihan menunjukkan bahwa subjek adalah peserta yang mengikuti Pelatihan Dzikir dengan antusias. Berperan aktif dalam mengikuti prosedur setiap sesi. Subjek memiliki interaksi yang baik dengan peserta lain dan mudah menangkap seluruh instruksi trainer dengan baik.

Dari hasil wawancara yang dilakukan kepada subjek, semula subjek menganggap masalah adalah beban sehingga terkadang merasakan kecemasan yang berlebihan. Akan tetapi, setelah mengikuti Pelatihan Dzikir, subjek menanggapi permasalahan dengan positif, lebih tenang, tingkat kecemasan yang berkurang dan mulai memahami bahwa segala kesulitan dan masalah haruslah diselesaikan dan meyakini bahwa Allah turut membantu dalam menyelesaikan masalah. disamping itu pemahaman tentang pengetahuan agama bisa didapat, sesi yang paling berkesan adalah dzikir dan wirid, sesekali subjek mengeluarkan air mata pada saat dzikir dan wirid dibacakan. Subjek mengaku ternyata maafnya Allah lebih dekat dibandingkan murkanya.

\section{d. Subjek 4 (nama initial: IP)}

Skor kebermaknaan hidup sebelum mengikuti Pelatihan Dzikir adalah 85, sedangkan skor kebermaknaan hidup setelah dzikir adalah 96, skor kebermaknaan hidup sebelum 
Pelatihan Dzikir masuk dalam katagori sedang.

Obeservasi selama pelatihan menunjukkan bahwa subjek adalah peserta yang mengikuti Pelatihan Dzikir dengan antusias. Dari hasil wawancara, subjek mengatakan mulai dapat memahami dan mengenal Allah sebagai dzat dengan sifat-sifatnya sehingga merasakan semakin dekat kepada Allah. Dengan adanya Pelatihan Dzikir menumbuhkan atau melahirkan kesadaran untuk senantiasa bersama Allah (ma'yatullah) sehingga tertanam bahwa Allah adalah satu satunya tempat bagi manusia untuk mengadu dan mengembalikan segala urusan. Sesi yang berkesan adalah sesi ma'rifatullah.

\section{e. Subjek 5 (nama initial: WR)}

Skor kebermaknaan hidup sebelum mengikuti Pelatihan Dzikir adalah 85, sedangkan skor kebermaknaan hidup setelah dzikir adalah 97. Hal ini menunjukkan bahwa ada peningkatan yang semula katagori sedang menjadi tinggi. Observasi selama pelatihan menunjukkan bahwa subjek adalah peserta yang mengikuti Pelatihan Dzikir yang semula kurang antusias menjadi antusias karena adanya game. Subjek mengaku sebelumnya kurang memahami tentang tujuan diciptakan di muka bumi. Setelah mengikuti pelatihan pemahaman tentang tujuan Allah menciptakan manusia dimuka bumi, subjek dapat memahami bahwa
Allah menciptakan manusia di muka bumi tak lain adalah hanya beribadah padanya. Subjek merasa lebih dekat dengan Allah. Pada sesi ma'rifatullah subjek merasa bahwa ternyata yang berhak sombong adalah Allah. Setelah pelatihan berlangsung, sesekali subjek melakukan dzikir di saat setelah selesai sholat. Subjek merasa lebih tenang dan menganggap bahwa kehidupan yang lebih berarti.

\section{f. Subjek 6 (nama initial: FA)}

Skor kebermaknaan hidup sebelum mengikuti Pelatihan Dzikir adalah 88, sedangkan skor kebermaknaan hidup setelah dzikir adalah 102. Skor kebermaknaan hidup sebelum Pelatihan Dzikir masuk dalam katagori sedang dan setelah Pelatihan Dzikir. Subjek mengalami peningkatan kebermaknaan hidup sebesar 14. Subjek mengalami peningkatan kebermaknaan hidup yang semula dalam katagori sedang menjadi tinggi.

Obeservasi selama pelatihan menunjukkan bahwa subjek adalah peserta yang mengikuti Pelatihan Dzikir dengan baik. Subjek kelihatan kurang aktif. Pada saat sesi muhassabah, subjek menangis. Dari hasil wawancara yang dilakukan kepada subjek setelah mengikuti dzikir subjek mengungkapkan bahwa subjek merasa lebih tenang, damai serta merasakan ada perubahan baik secara wawasan terlebih wawasan tentang keagamaan sehingga semakin 
merasa dekat dengan Allah SWT. Subjek mengaku, sebelum mengikuti Pelatihan Dzikir kondisi subjek diliputi perasaan bimbang, ragu dan kurang memahami keberadaan Allah lebih dekat. Subjek merasa sesi yang sangat berkesan adalah sesi ma'rifatullah. Setelah Pelatihan Dzikir kondisi fisiknya lebih segar dan lebih bersemangat, terutama ketika sholat membuat hati menjadi tenang dan damai.

\section{PEMBAHASAN}

Analisis data yang telah dilakukan menunjukkan bahwa hipotesis yang diajukan dalam penelitian ini diterima. Ada perbedaan kebermaknaan hidup pada remaja akhir yang mengikuti pelatihan dzikir dengan yang tidak mengikuti pelatihan dzikir. Subjek yang memperoleh pelatihan dzikir mengalami peningkatan kebermaknaan hidup lebih tinggi dibandingkan dengan remaja yang tidak mengikuti pelatihan dzikir.

Sebelum mendapatkan perlakuan, secara umum kebermaknaan hidup subjek berada pada katagori sedang dan rendah. Setelah diberi perlakuan berupa Pelatihan Dzikir rerata skor kebermaknaan hidup pada kelompok eksperimen menunjukkan peningkatan. Sedangkan rerata skor skala kebermaknaan hidup pada kelompok kontrol tidak mengalami peningkatan seperti yang terjadi pada kelompok eksperimen. Hal ini membuktikan bahwa hipotesis diterima bahwa ada perbedaan kebermaknaan hidup antara kelompok eksperimen dengan kelompok kontrol.

Hasil pengujian tersebut mendukung pendapat Subandi (2009) bahwa dzikir merupakan salah satu cara untuk meningkatkan kebermaknan hidup terhadap jamaah pengajian. Kelompok subjek yang diberi perlakuan Pelatihan Dzikir (KE) menunjukkan kebermaknaan hidup yang lebih tinggi dibandingkan dengan kelompok subjek yang tidak diberikan Pelatihan Dzikir (KK). Hal ini ditujukkan dari selisih antara prates dan pascates KE yang lebih tinggi daripada selisih prates dan pascates KK. Hasil ini menunjukkan bahwa Pelatihan Dzikir efektif untuk meningkatkan kebermaknaan hidup pada remaja.

Hasil penelitian lain diantaranya adalah penelitian yang dilakukan oleh Hemmy (2002) terhadap pasien penyakit jantung yang menjadikan dzikir sebagai strategi coping, sehingga individu dapat membuka pintu hati untuk mendapatkan bimbingan lahir dan batin dari Allah, sehingga individu bisa menjadi lebih sehat, baik fisik, psikis, sosial maupun keagamaan.

Pelatihan mengunakan metode experiential learning, ceramah, rileks, menarik dan menyenangkan. Peserta mendapatkan pengalaman kemudian diajak untuk menghayati pengalaman dan merenungkan (refleksikan) kemudian menyadari perasaan dan reaksi-reaksi yang muncul. Setelah itu peserta diajak untuk mengungkapkan hal-hal yang dialami saat latihan berlangsung, yang 
kemudian diolah bersama baik kelompok maupun klasikal sehingga timbullah satu kesadaran tentang suatu perilaku.

Pelatihan dzikir terdiri atas beberapa sesi yaitu ice breaking, ma'rifatullah, ma'rifatul insan, mendengarkan dan mentadaburi Al-Quran, tadzkiyatun nafs, dzikir dan wirid, sholat, problematika hidup, sholat malam dan muhasabah. Materi pertama adalah sesi Bina suasana yang disisi dengan Perkenalan. Sesi ini diikuti oleh 6 peserta yang bertujuan menciptakan kondisi awal yang mendukung jalannya pelatihan Dzikir, peserta yang lain dan mencairkan suasana peserta dengan situasi sekitar agar peserta bisa all out mengikuti pelatihan sehingga tumbuh saling menghormati, menghargai satu sama lain (Harjana, 1995).

Materi kedua dalam pelatihan Dzikir ialah Ma'rifatullah (mengenal Allah). Materi tersebut termasuk experiential value (nilai-nilai penghayatan). Keyakinan dan penghyatan akan nilai-nilai kebenaran, kebajikan, keindahan, keimanan dan keagamaan serta cinta kasih, menghayati dan meyakini suatu nilai dapat menjadikan seseorang berarti hidupnya (Bastaman, 2008). Materi ini memberikan kesem-patan untuk menggali apa yang telah diketahui peserta dan meluruskan pendapat-pendapat yang keliru tentang siapa Tuhan itu dengan mengenalkan Allah sebagai Dzat yang maha pencipta dan sebagai satu satunya tuhan yang mempunyai sifat kesempurnaan. Sifat sifat kesempurnaan Tuhan dituangkan dalam asmaul husna. Ustadz menerangkan satu persatu asmaul husna agar peserta memahami masing masing sifat Allah dan tumbuh keyakinan serta kepercayaan yang kuat tentang Allah dengan segala kekuasaannya. Keimanan tentang adanya Tuhan dengan kesempurnaannya akan menumbuhkan jiwa tauhid dihati sehingga termotivasi untuk selalu mendekatkan diri kepada Allah (Wahid, dalam Mubarok, 1994).

Pada sesi ini peserta diajak untuk mampu melihat diri dari perspektif tuhannya, agar peserta termotivasi untuk mengikuti seluruh acara pelatihan Dzikir sebagai salah satu cara untuk memperbaiki diri. Sesi ini akan membawa peserta pada pardigma berpikir apa hakikat dari semua yang telah dilakukan dengan kata lain tujuan hakiki peserta dalam menjalani kehidupan, dan membuat peserta termotivasi untuk mengikuti pelatihan demi menjalankan sesuatu yang mempunyai tujuan hakiki. Menurut Stoltz (Sumanto, 2006), selama menjalani pelatihan, pada diri peserta sudah terarah untuk menjiwai setiap sesi yang bermuara pada tujuan hakiki hidupnya, berdasarkan nilai yang dianut.

Pada sesi ini juga terdapat video tentang alam yang berdzikir seperti awan yang membentuk tulisan Allah, pohon yang membentuk tulisan La illaha illallah dan contoh azab yang diberikan Allah kepada hambanya yang lalai. Sesi ini untuk menambah rasa keimanan dan keyakinan terhadap Allah. Dalam subsesi melihat video akan memberikan suatu 
pengetahuan dan pemahaman bahwa semua mahluk Tuhan tidak terkecuali selalu melakukan dzikir, tidak hanya manusia saja. Adapun unsur belajar dari pengalaman melalui melihat video adalah adanya beberapa contoh azab bagi orang yang lalai terhadap Tuhannya dan melakukan perbuatan maksiat. Tujuan penayangan adalah agar dijadikan pelajaran yang terpenting bagi peserta untuk selalu meningkatkan kebermaknaan hidupnya dan menjaga setiap aktivitasnya dengan mengingat Allah, serta memahami konsekuensi duniawi dari keyakinan dan tindakan (Glock dan Stark, dalam Ancok \& Suroso, 2011). Pada subsesi melihat video dimaksudkan menjadikan peserta ingat bahwa setiap aktivitas akan dilakukan disertai keyakinan bahwa setiap perbuatan memiliki konsekuensi sehingga selalu menggangap hidupnya bermakna.

Pada materi ketiga adalah Ma'rifatul insan. Sesi ini termasuk dalam creative value (nilai-nilai kreatif). Nilai-nilai kreatif antara lain adalah kegiatan berkarya, bekerja, menciptakan serta melaksanakan tugas dan kewajiban sebaik-baiknya dengan tanggung jawab menekuni suatu pekerjaan dan meningkatkan keterlibatan dengan sebaik-baiknya (Bastaman, 2008). Melalui materi ini peserta diajak untuk mengetahui arti dzikir yang sebenarnya. Kemudian peserta diajak melakukan dzikir bersama-sama dengan Ustaz dengan nafas tafakur artinya dzikir dilakukan dengan teknik pernafasan, disetiap tarikan nafas menyebut asma Allah. Didalam materi dzikir dan wirid peserta juga diajak membaca Al-Quran. Karena membaca Al-Quran merupakan salah satu bentuk Dzikir. Al-Quran merupakan petunjuk hidup bagi umatnya agar selamat dunia akhirat sehingga harus dibaca, dipahami dan diamalkan.

Materi keempat adalah mendengarkan dan mentadaburi Al-Qur'an Sesi ini bertujuan untuk memberikan pemahaman kepada peserta bahawa membaca AlQura'an adalah perwujudan dzikir kepada Allah SWT. Sesi ini mengajak peserta untuk melakukan interaksi dengan Al-Qur'an yang kemudian menjadikan AlQur'an sebagai sarana dzikir. Sesi ini dimulai dengan membagikan lembaran ayat-ayat Al-Qur'an tentang ketenangan jiwa. Peserta dipersilahkan untuk membacanya dan merenungi ayat-ayat tersebut. Fasilitator menggali hasil perenungan peserta tentang ayat tersebut.

Selanjutnya materi kelima Tazkiyatun Nafs. Sesi ini bertujuan memotivasi peserta untuk mengembangkan jiwa yang sehat secara progresif dengan melakukan kedekatan hati kepada Allah SWT. Fasilitator meminta peserta untuk menuliskan pada kertas bergambar hati tentang ada saja yang masih ada penyakit hatinya. Kemudian fasilitator memberikan komentar tentang pengertian hati, karakteristik hati, macam-macam penyakit hati, dan sumbernya. Materi ke enam dzikir dan wirid. Yang dimaksud dzikir Al-quran dan As-Sunnah adalah segala macam bentuk mengingat Allah baik dengan membaca Tahlil, Tasbih, Tahmid, Tadis, Takbir, Tasmiyah, 
Qira'atul Quraan maupun membaca doadoa yang matsyur dari rasullulah. Ibnu Qoyyim (An-Nasa'i, 2005) menjelaskan makna dzikir ada tiga. Pertama ialah mengenal Allah dalam kaitannya dengan Tauhid rububiyah, uluhiyah, nama-nama dan sifat sifatnya. Kedua adalah dzikir dengan menyebut asma Allah melalui lisan dan hati. Ketiga adalah dzikir dalam arti mempelajari dan memahami Hukum Allah baik perintah maupun larangannya.

Materi ketujuh ialah Sholat. Sholat merupakan Wujud tertinggi dari dzikir yang di dalamnya terdapat doa, Dzikir, Sholawat, membaca Al-Quran, istighfar, dan takbir. Sholat merupakan kewajiban bagi umat Islam yang harus dilaksanakan 5 kali sehari. Pada sesi ini diterangkan juga macam-macam sholat sunnah dengan keutamaan dan manfaatnya, sehingga sholat dapat digunakan untuk mengatasi permasalahan. Oleh sebab itu melalui materi ini peserta diajarkan sholat yang benar dan khusuk serta manfaat dari sholat (aspek terapeutik).

Pengalaman mengerjakan sholat yang membuat jiwa jadi tenang dan dapat mengatasi kecemasan, sehingga akal dan pikiran menjadi jernih akan membawa pada kebermaknaan Hidup, karena terbentuknya makna hidup dipengaruhi salah satunya adalah faktor pengalaman (Meichati, 1987). Materi kedelapan problematika kehidupan. Problematika kehidupan merupakan cara mengungkapkan masalah yang selama ini dipendam. Dalam materi ini diawali dengan problem hidup. Peserta dimintai mengungkapkan masalah yang sedang dihadapi, kemudian trainer memberikan penjelasan bahwa masalah merupakan sunahtullah (ketentuan Allah), bagaimana cara menyikapinya. Di dalam materi katarsis terdapat sesi pembersihan hati. Peserta diajak mengenali hati, karakteristik hati, cara menjaga dan memelihara hati. Karena hati merupakan pusat bagi seseorang dalam kebermaknaan hidup. Pendapat di atas mendukung pernyataan yang diutarakan (Bastaman, 2008) dalam attitude value (nilai-nilai bersikap), yaitu menerima dengan penuh ketabahan, kesabaran dan keberanian segala bentuk penderitaan yang tidak mungkin dielakkan lagi.

Sesi kesembilan adalah Qiyamullail Sesi ini bertujuan memotivasi peserta untuk membiasakan sholat malam dan menjadikan sarana berdialog dan menjalani keterbukaan dengan Allah. Sholat malam dilakukan berjamaah. Setelah melakukan sholat malam secara berjamaah peserta dan imam sholat membaca Istigfar 33 kali, sholawat 33 kali, tasbih 33 kali, tahmid 33 kali, dan takbir 33 kali. Yang terakhir kesepuluh muhasabbah (perenungan). Peserta diajak untuk merenungi setiap perilaku selama ini dengan harapan agar lebih mendekatkan diri dengan Allah SWT.

Pelatihan dzikir secara teratur diharapkan remaja mampu menembus pikiran dan alam bawah sadarnya menuju gelombang alfa, akibatnya pikiran akan menjadi jernih, perasaan akan menjadi tenang serta mampu meningkatkan kebermaknaan hidupnya (Subandi, 2009). 
Hasil penelitian menunjukkan bahwa sebagian besar subjek mengalami peningkatan kebermaknaan hidup. Hasil analisis skor Skala Kebermaknaan Hidup pada masing-masing subjek tidak sama. Bahkan ada beberapa subjek yang tidak mengalami peningkatan. Hal tersebut disebabkan adanya perbedaan tingkat keaktifan dalam mengikuti prosedur pelatihan dzikir yang diberikan dan tingkat keseriusan masing-masing subjek dalam mengikuti proses pelatihan, termasuk didalamnya kemauan dan kesediaan untuk berlatih, baik dalam situasi pelatihan maupun situasi yang senyatanya dalam kehidupan sehari-hari. Pada kelompok kontrol terdapat salah satu subjek yang semula dalam kategori rendah menjadi tinggi hal ini dikarenakan waktu pelatihan dilaksanakan dua minggu sebelum bulan Romadon, hal ini memungkinkan subjek tersebut mendekatkan diri kepada Allah.

Dari pembahasan di atas dapat disimpulkan bahwa pelatihan dzikir dapat digunakan untuk meningkatkan kebermaknaan hidup peserta pelatihan. Dengan demikian pelatihan inipun dapat dijadikan salah satu alternatif solusi untuk meningkatkan kebermaknaan hidup pada remaja sehingga remaja dapat bertindak dan berpikir positif atas makna hidupnya sendiri. Perbedaan kebermaknaan hidup tidak terlepas dari tahap-tahap pelatihan yang mengajak peserta untuk memperoleh pengetahuan dan pengalaman untuk meningkatkan kebermaknaan hidup. Keberhasilan peserta dalam makna hidupnya, dibuktikan dengan adanya perbedaan tingkat kebermaknaan hidup antara subjek yang mendapat pelatihan dengan subjek yang tidak mendapat pelatihan.

\section{SIMPULAN DAN SARAN}

\section{Simpulan}

Berdasarkan hasil penelitian dan pembahasan dapat disimpulkan bahwa ada perbedaan peningkatan kebermaknaan hidup antara kelompok subjek yang mendapatkan perlakuan dzikir (KE) dan kelompok subjek yang tidak mendapatkan perlakuan Pelatihan Dzikir (KK). Subjek yang memperoleh Pelatihan Dzikir mengalami peningkatan kebermaknaan hidup lebih tinggi daripada subjek yang tidak mendapatkan Pelatihan Dzikir. Hal tersebut membuk-tikan bahwa Pelatihan Dzikir cukup efektif untuk membantu meningkatkan kebermaknaan hidup pada mahasiswa. Pelatihan Dzikir ini dapat mengatasi gejala fisik, gejala psikologis dan gejala perilaku yang ditimbulkan akibat ketidakbermaknaan hidup. Hal ini terjadi karena Pelatihan Dzikir merupakan metode yang dapat mententramkan hati sehingga dapat meningkatkan kebermaknaan hidup.

\section{Saran}

Berdasarkan penelitian yang dilakukan, peneliti memberikan saran bagi beberapa pihak. Pertama bagi subyek penelitian. Hasil penelitian ini membuktikan bahwa Pelatihan Dzikir dapat 
meningkatkan kebermaknaan hidup pada mahasiswa remaja akhir. Disarankan kepada mahasiswa remaja akhir agar menerapkan dzikir dalam kehidupan sehari-hari agar tumbuh kesadaran selalu bersama Allah.

Kedua, bagi bagi peneliti selanjutnya. Diharapkan lebih menyempurnakan penelitian selanjutnya dengan memperhatikan hal-hal yang dapat memengaruhi, peneliti hanya menggunakan 12 subjek, sehingga disarankan untuk menambah jumlah subjek karena menambah keakurasian dan kecermatan alat ukur. Dalam pelatihan ini digunakan waktu hanya dalam 2 hari sehingga keterbatasan waktu memengaruhi efek terhadap subjek antara lain kurang dapat mencermati materi lebih dalam. Sebaiknya durasi waktu dalam pelatihan ditambah agar subjek dapat merasakan efeknya lebih mendalam. Diharapkan kepada peneliti selanjutnya untuk dapat memantau KK hal ini karena ada beberapa ancaman internal seperti ancaman kematangan, testing, moralitas dapat memengaruhi keadaan subjek.

Ketiga, bagi lembaga/institusi pendidikan. Diharapkan institusi pendidikan dapat menjadikan Pelatihan Dzikir sebagai salah satu program untuk meningkatkan kebermaknaan hidup, sehingga pelatihan tersebut berjalan secara berkelanjutan.

\section{DAFTAR PUSTAKA}

An-Nasa'i. (2005). Amalan Seumur Hidup. Yogyakarta: Publisher.

Azwar, S. (2003). Reliabilitas dan Validitas. Yogyakarta: Pustaka Pelajar.

Ancok, D. \& Suroso, F.N. (2011) Psikologi Islami: Solusi Islam Atas Problem-Problem Psikologis. Yogyakarta: Pustaka Pelajar.

Bastaman. H.D. (1996). Meraih Hidup Bermakna. Jakarta: Paramadina.

Bastaman. H.D. (2005). Integrasi Psikologi Dengan Islam: Menuju Psikologi Islami. Yogyakarta: Pustaka Pelajar.

Bastaman, H.D. (2008). Logoterapi: Psikologi untuk Menemukan Makna Hidup dan Meraih Hidup Bermakna. Jakarta: PT. Raja Grafindo Persada.

Budiarto, D. (1982). Metode Instrumentalisme - Eksperimentalisme John Dewey. Skripsi (tidak diterbitkan). Yogyakarta: Fakultas Filsafat Universitas Gadjah mada.

Eniatun. (2004). Hubungan Antara Dzikir dan Kebermaknan Hidup Santri di Pondok Pesantren, Skripsi (Tidak Di Terbitkan). Yogyakarta : Fakultas Psikologi Universitas Wangsa Manggala. 
Frankl. V.E. (2004). Mencari Makna Hidup. Terjemahan Man's Search Meaning. Bandung: Nusantara.

Harjana, A. (1995). Penghayatan Agama Yang Otentik Dan Tidak Otentik. Jakarta: Kanisius.

Harre, R \& Lamb,R. (1996). Ensiklopedia psikologi. Jakarta: Arcan.

Hartati. (2002). Pengaruh Pelatihan Dzikir Terhadap Peningkatan Kebermaknaan Hidup. Skripsi (tidak diterbitkan). Yogyakarta: Fakultas Psikologi Universitas Gadjah mada.

Hawari, D. (1988). Al-Quran: Ilmu Kedokteran Jiwa Dan Kesahatan Jiwa. Yogyakarta: Dhana Bhakti Primayogya.

Haryanto, S. (2008). Psikologi sholat kajian aspek-aspek psikologis ibadah sholat. Yogyakarta: Pustaka pelajar.

Haryanto, S. (1996). Profil Pondok Pesantren Suryalaya: Tempat Rehabilitasi Remaja Korban Penyalahgunan Narkotika Dengan Pendekatan Agama. Laporan penelitian (tidak diterbitkan). Yogyakarta: Universitas Gadjah Mada.

Hemmy, H.A. (2002). Dzikrullah Suatu Transcendental Being dan Terapi. Surakarta: Indigenous. http;//www.regional.kompas.com. 2009). BNN: Prestasi pemberantasan narkoba menurun. Edisi 31 desember 2009. Diakses pada tanggal 27 juni 2010.

Ilham, M. A. (2005). Renungan-renungan Dzikir. Depok: Intuisi Press

Koeswara, E. (1992). Logoterapi Psikoterapi Viktor Frankl. Yogyakarta: Kanisius.

Latipun, E. (2006). Psikologi Eksperimen. Malang: Universitas Muhammadiyah Malang.

Meichati, S. (1992). Psikologi Remaja. Jakarta: Usaha Nasional.

Mubarok, A. (1994). Psikologi Dakwah. Jakarta: Pustaka Firdaus.

Monks, F.J., Knoers, A.M.P., dan Haditono, S.R. (2009). Psikologi Perkembangan dalam Berbagai Bagiannya. Yogyakarta: Gadjah Mada University Press.

Purba, I. (2005). Powerfull Dzikir Terhadap Penurunan Kecemasan Pada Mahasiswa. Skripsi (tidak diterbitkan). Yogyakarta: Fakultas Psikologi Universitas Wangsa Manggala. 
Purwanti. (2001). Panduan meraih Sumanto. (2006). Kajian Psikologis keutamaan-keutamaannya dan Kebermaknaan Hidup. Buletin menepis kendala-kendalanya. Bandung: Pustaka Al-hijazy

Subandi. (2009). Psikologi Dzikir: Studi Fenomenologi Transformasi Religius. Yogyakarta: Pustaka pelajar. Psikologi, 4 (2), 115-135.

Supriadi. (2006). Petunjuk jalan. Jakarta: Media dakwah

Yusuf, S.(2004). Psikologi Perkembangan Anak dan Remaja. Bandung: Remaja Rosda. 